\title{
REPORTS OF CASES
}

IN THE

\section{COURTS OF STAR CHAMBER AND HIGH COMMISSION.}
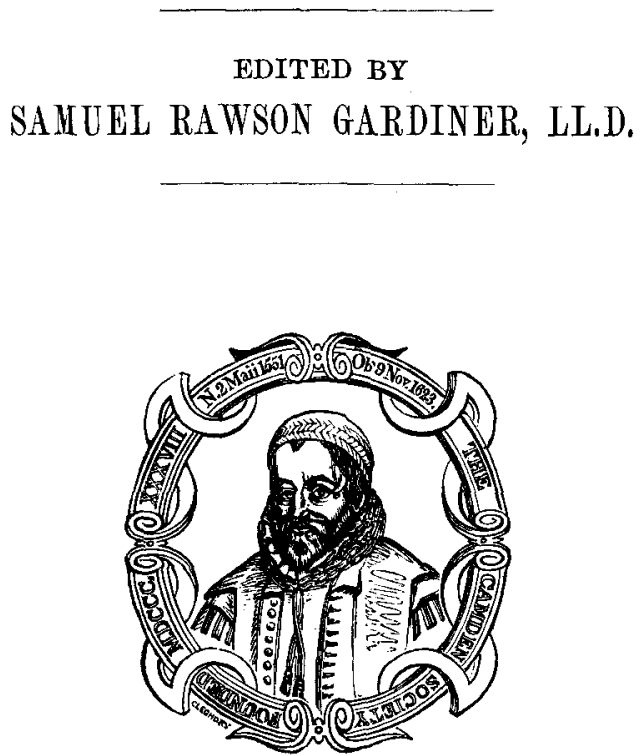

PRINTED FOR THE CAMDEN SOCIETY. M.DCCC.IXXXv1. 
WEGTMINSTER:

PRINTED BY NICHOLS AND SONS,

25, PARLIA MENT STREET.

[NEW SERIES XXXIX.] 


\title{
COUNCIL OF THE CAMDEN SOCIETY \\ FOR THE YEAR 1886-7.
}

\author{
President, \\ THE RIGHT HON. THE EARL OF VERULAM, F.R.G.S. \\ SAMUEL R. BIRD, ESQ., F.S.A. \\ JAMES J. CARTWRIGH'T, ESQ., M.A., F.S.A., Treasurer. \\ WILLIAM CHAPPELL, ESQ., F.S.A. \\ F. W. COSENS, ESQ., F.S.A. \\ REV. J. SILVESTER DAVIES, M.A., F.S.A. \\ THE HON. HAROLD DILLON, F.S.A. \\ JAMES E. DOYLE, ESQ. \\ REV. J. WOODFALL EBSWORTH, M.A., F.S.A. \\ JAMES GAIRDNER, ESQ., Secretary. \\ SAMUEL RAWSON GARDINER, ESQ., M.A., LL.D., Director. \\ JOHN W. HALES, ESQ., M.A. \\ REV. DR. JESSOPP. \\ ALEXANDER MACMILLAN, ESQ., F.S.A. \\ THE EARL OF POWIS, LL.D. \\ HENRY REEVE, ESQ., D.C.L., C.B., F.S.A.
}


The Council of the Camden Society desire it to be understood that they are not answerable for any opinions or observations that may appear in the Society's publications; the Editors of the several Works being alone responsible for the same. 